University of Nebraska - Lincoln

DigitalCommons@University of Nebraska - Lincoln

USDA Wildlife Services - Staff Publications

U.S. Department of Agriculture: Animal and Plant Health Inspection Service

$10-1-2021$

\title{
Adaptation of an artificial bait to an automated aerial delivery system for landscape-scale brown treesnake suppression
}

\author{
Rafael A. Garcia \\ USDA ARS Eastern Regional Research Center, rafael.garcia@usda.gov \\ Thomas W. McAuliffe \\ USDA APHIS National Wildlife Research Center \\ Lorelie P. Bumanlag \\ USDA ARS Eastern Regional Research Center, Lorelie.Bumanlag@ars.usda.gov \\ Shane R. Siers \\ USDA Animal and Plant Health Inspection Service (APHIS), shane.r.siers@usda.gov \\ Bruce A. Kimball \\ USDA APHIS National Wildlife Research Center, bruce.kimball@ars.usda.gov \\ Follow this and additional works at: https://digitalcommons.unl.edu/icwdm_usdanwrc \\ Part of the Natural Resources and Conservation Commons, Natural Resources Management and \\ Policy Commons, Other Environmental Sciences Commons, Other Veterinary Medicine Commons, \\ Population Biology Commons, Terrestrial and Aquatic Ecology Commons, Veterinary Infectious Diseases \\ Commons, Veterinary Microbiology and Immunobiology Commons, Veterinary Preventive Medicine, \\ Epidemiology, and Public Health Commons, and the Zoology Commons
}

Garcia, Rafael A.; McAuliffe, Thomas W.; Bumanlag, Lorelie P.; Siers, Shane R.; and Kimball, Bruce A., "Adaptation of an artificial bait to an automated aerial delivery system for landscape-scale brown treesnake suppression" (2021). USDA Wildlife Services - Staff Publications. 2476.

https://digitalcommons.unl.edu/icwdm_usdanwrc/2476

This Article is brought to you for free and open access by the U.S. Department of Agriculture: Animal and Plant Health Inspection Service at DigitalCommons@University of Nebraska - Lincoln. It has been accepted for inclusion in USDA Wildlife Services - Staff Publications by an authorized administrator of DigitalCommons@University of Nebraska - Lincoln. 


\title{
Adaptation of an artificial bait to an automated aerial delivery system for landscape-scale brown treesnake suppression
}

\author{
Rafael A. Garcia - Thomas W. McAuliffe - Lorelie P. Bumanlag • \\ Shane R. Siers $(\mathbb{D} \cdot$ Bruce A. Kimball
}

Received: 26 August 2020/ Accepted: 3 May 2021 / Published online: 15 May 2021

(C) This is a U.S. government work and not under copyright protection in the U.S.; foreign copyright protection may apply 2021

\begin{abstract}
Dead neonatal mice are currently used as bait for delivery of toxin to invasive brown treesnakes (Boiga irregularis) on Guam; once deployed in the field the mice are highly attractive to the snakes but only for about four days. An artificial bait containing a mixture of fats mimicking those in skin of the mice is also highly attractive to the snakes and remains attractive 2-3 times longer. The artificial bait, however, costs more than the mice, and is more difficult to attach to the capsules of a novel aerial bait delivery system. This paper describes a reformulation of the bait which reduced the ingredient cost to $11 \%$ of its former value, without compromising its attractiveness to free-ranging snakes. Three lipid formulations using
\end{abstract}

R. A. Garcia $(\bowtie) \cdot$ L. P. Bumanlag

United States Department of Agriculture, Agricultural Research Service, Eastern Regional Research Center, Dairy and Functional Foods Research Unit, 600 East Mermaid Lane, Wyndmoor, PA 19038, USA

e-mail: rafael.garcia@usda.gov

T. W. McAuliffe

United States Department of Agriculture, Animal and

Plant Health Inspection Service, Wildlife Services,

National Wildlife Research Center, 210 Amau'ulu Road,

P.O. Box 10880, Hilo, HI 96720, USA

\section{S. R. Siers}

United States Department of Agriculture, Animal and Plant Health Inspection Service, Wildlife Services,

National Wildlife Research Center, 233 Pangelinan Way,

Barrigada, GU 96913, USA different source materials to produce the same fatty acid profile target were tested along with two levels of pork fat to yield six test formulations. No differences in bait disappearance were noted in field testing of the baits, indicating that decisions regarding bait formulation could be made on the basis of cost without sacrificing efficacy. Separately, testing of 17 commercially available adhesives identified five for field testing. Among these, two demonstrated strong, weather-resistant bonds between the oily surface of the artificial baits and the bait capsules as evidenced by only $13.4 \%$ and $4.5 \%$ of baits falling off suspended capsules. Importantly, neither of these adhesives impacted bait removal by snakes in field trials in

\author{
B. A. Kimball \\ United States Department of Agriculture, Animal and \\ Plant Health Inspection Service, Wildlife Services, \\ National Wildlife Research Center, 3500 Market Street, \\ Philadelphia, PA 19104, USA \\ B. A. Kimball \\ Monell Chemical Senses Center, 3500 Market Street, \\ Philadelphia, PA 19104, USA
}


comparison to baits with no adhesive.. The results represent an advance in technology development for landscape-scale suppression of brown treesnake populations.

Keywords Adhesive - Artificial bait - Boiga irregularis $\cdot$ BROWN treesnake $\cdot$ Formulation $\cdot$ Guam

\section{Introduction}

The brown treesnake (Boiga irregularis, BTS) was accidentally introduced to Guam in the late 1940s or early 1950s, probably from the Admiralty Islands (Fritts and Rodda 1998). In the absence of any natural predators of BTS, the snake population grew unchecked, spreading to all areas of the island. Because there are no snakes native to Guam, native fauna are naive to snake predation and highly vulnerable. The direct ecological impact has been extirpation or severe population reduction of most native vertebrates (Rodda and Savidge 2007). Indirect impacts include altered patterns of seed dispersal, invertebrate abundance, herbivory by insects, and potentially pollination (Moore et al. 2015; Freedman et al. 2018; Pollock et al. 2020).

The BTS is currently the subject of a cooperative program between Federal, state, and territorial government agencies to control snake populations on the island and prevent its spread to other islands of the Pacific region ${ }^{1}$. The importance of BTS was recognized in the National Defense Authorization Act of 2009 that required the U. S. Department of Defense to establish a comprehensive program to control, and to the extent practicable, eradicate BTS from military facilities on Guam ${ }^{2}$ (Clark et al. 2017).

Efforts to remove BTS from Guam primarily rely on two primary strategies-live-trapping and delivery of toxic baits (Engeman et al. 2018). Both strategies exploit limited prey availability by offering preferred food items to snakes. Traps with live mouse lures are effective for monitoring and reducing snake numbers

\footnotetext{
1 Brown Tree Snake Control and Eradication Act of 2004, Pub. L. No. 108-384 Section 7, 118 STAT. 2224 (2004).

2 Duncan Hunter National Defense Authorization Act for Fiscal Year 2009, Pub. L. No. 110-417 Section 316, 122 STAT. 4410 (2008).
}

in conservation zones, around electric utility infrastructure, and in areas of high risk of accidental export such as outbound cargo ports (Vice and Pitzler 2002; Vice et al. 2005). Toxic baits are prepared using dead neonatal mice (DNM) and acetaminophen tablets (Savarie et al. 2001); while highly preferred by BTS, these baits have an extremely short period of field stability, and they are attractive to non-target species (Johnston et al. 2002). The recent development of an automated Aerial Delivery System (ADS) to distribute toxic bait (DNM) will enable cost-effective suppression of snake activity on a landscape scale (Siers et al. 2019, 2020). Aerial baiting was developed to treat large, remote forest plots on rugged terrain in areas that are not practically accessible for ground-based operations. ADS bait cartridges are designed to hang in the forest canopy where baits are encountered by arboreally-foraging BTS, preventing baits from falling to the forest floor where they are more likely to be consumed by terrestrial nontarget species such as crabs. Incorporation of a durable artificial bait, to replace DNM, could make such efforts more effective and affordable.

A previous study demonstrated that an artificial fat mixture ("mouse butter") based on the fatty acid profile of DNM skin is effective at attracting BTS, but ingestion only occurs when the mouse butter is paired with an appropriate substrate such as SPAM ${ }^{\circledR}$, a canned pork meatloaf product (Kimball et al. 2016). A subsequent study (unpublished) developed a process for production of an artificial bait similar to SPAM which incorporated mouse butter and preservatives. This formulation produced extremely desirable results in field trials. The bait remained attractive to BTS for at least eight and as many as 14 days in the field, compared to DNM which spoil quickly and are rendered unpalatable by day three or four. The bait also demonstrated good weatherability traits; during field trials it was observed that the baits swelled when rainwater pooled in the PVC bait tubes employed for evaluation trials, but then became firm again upon drying and were still attractive to snakes.

The present study was directed at overcoming challenges to using the artificial bait in the ADS. The bait must be affixed to the biodegradable ADS bait cartridge, and the bond must be reliable under exposure to varying tropical weather conditions. The hot-melt adhesive ("hot glue") currently used to create a bond between DNM and the capsule has 
proven ineffective with the greasy artificial bait, but selection of a new adhesive has the potential to introduce repellant sensory signals, deterring consumption by BTS. Separately, the ingredient cost for producing an individual artificial bait was greater than the cost of a DNM (about $\$ 0.20$ when purchased in large quantities). Mouse butter, comprising ARASCO oil (a fungal oil produced through biotechnology) and several reagent grade synthetic fats, accounted for 95\% of ingredient costs. Reformulation using food grade fats could substantially reduce cost, but also might reduce effectiveness, as such fats (e.g. butterfat, coconut oil) retain some aroma of their source material. Finally, the artificial bait contains pork fat simply because it was formulated to have a composition very similar to SPAM; mouse butter was initially found to be effective when applied to the surface of SPAM or the artificial bait. When mouse butter was later incorporated into the formula of the artificial bait, it displaced only a portion of the pork fat in the formula. Although artificial bait incorporating mouse butter has proven effective in field trials, the mixing of mouse butter and pork fat yields an overall fatty acid profile that is a poorer mimic of the profile of DNM skin, and it is possible that this is suppressing the bait effectiveness.

\section{Methods}

Bait production

All baits were prepared at the NWRC Hawaii Field Station (Hilo, HI). For a typical batch, partially frozen raw ground pork shoulder (1091 g) was combined with raw ground pork back fat (varying mass), modified potato starch (41.7 g), salt (59.8 g), table sugar (9.05 g), ice (approx. $140 \mathrm{~g}$ ), the preservatives potassium sorbate $(3.62 \mathrm{~g})$ and sodium nitrite $(0.18 \mathrm{~g})$, and mouse butter (54 g; Table 1). All ingredients were mixed in a vacuum mixer (WhipMix VPM2) under reduced pressure. The batter was transferred to foil retort pouches (approx. $280 \mathrm{~g}$ per pouch), spread using a rolling pin to a uniform thickness of approximately $1 \mathrm{~cm}$, and vacuum sealed. The pouches were processed for $80 \mathrm{~min}$ at $113{ }^{\circ} \mathrm{C}$ in a high-pressure canner (All American Pressure Cooker/ Canner Model 910). The final product was very similar to SPAM in appearance, composition, texture, and density (Figs. 1 and 2).

Elsewhere in this document, when the pork fat content of the bait is mentioned, it refers to the amount of the ingredient raw ground pork back fat rather than the analytic fat content of the bait. These will differ because the pork back fat is not pure fat, and the pork shoulder is not fat free. It should be understood that a formulation with no added pork fat actually does have some pork fat, but this fat originated in the ground pork shoulder.

\section{Bait attachment}

Seventeen commercially available adhesives were qualitatively evaluated (Table 2). Each adhesive was used according to the manufacturer directions to bond a bait cube to a flat sheet of the ADS capsule material. Bond strength was evaluated by its ability to hold a bait cube when the sheet was hung vertically. Performance of adhesives was informally ranked based on bond curing time, bond strength and durability, and handling/use requirements (e.g. heated adhesive, dry bait surface, 2-surface application).

Field adhesive durability tests were conducted at the Keaukaha Military Reservation located in Hilo, HI over the period of 2-16 April 2019. Refrigerated bait pouches were allowed to reach room temperature, cut into 20 individual baits, and blotted dry with paper towels. A dab of adhesive (ca. $1.5 \mathrm{~cm}$ diameter) was placed inside the ADS capsule and a single bait placed directly on the adhesive. Attached baits were allowed to dry overnight before field deployment. In the field, bait capsules were attached to strings and hung from a line $2 \mathrm{~m}$ above the ground (re 3). Fifteen baits representing each of the five adhesives were distributed at each of three locations in the facility's Area C (Fig. 3) to ensure exposure to the various environments (i.e. closed canopy, partial canopy, and open canopy). Baits were monitored daily for 14 days and inspected for attachment and visible signs of degradation. Cumulative data (the number of baits remaining attached to the bait capsule at day 14) were subjected to $\chi^{2}$ analyses to determine if results differed among the three locations (canopy conditions) and among the five adhesive types. 
Table 1 Ingredients (g/ $100 \mathrm{~g}$ ) for mouse butter and experimental reformulations
${ }^{a}$ Arachidonic acid single cell oil (DSM Nutritional Products)

${ }^{\mathrm{b}}$ Evening primrose oil

\begin{tabular}{lcrc}
\hline Ingredient & "Original” mouse butter & $\mathrm{EPO}^{\mathrm{b}}$ substitution & Natural fats substitution \\
\hline ARASCO $^{\mathrm{a}}$ & 33.9 & 29.3 & 28.0 \\
Trilaurin & 3.1 & 2.8 & \\
Trimyristin & 4.4 & 4.4 & \\
Tripalmitin & 15.3 & 10.5 & \\
Tristearin & 6.1 & 4.4 & 8.6 \\
Trilinolein & 37.3 & & 18.0 \\
EPO & & 48.6 & 5.0 \\
Butterfat & & & 40.4 \\
Coconut oil & & & 0.01 \\
Safflower oil & & 0.01 & 0.01 \\
BHA & 0.01 & 0.01 & \\
BHT & 0.01 & & \\
\hline
\end{tabular}

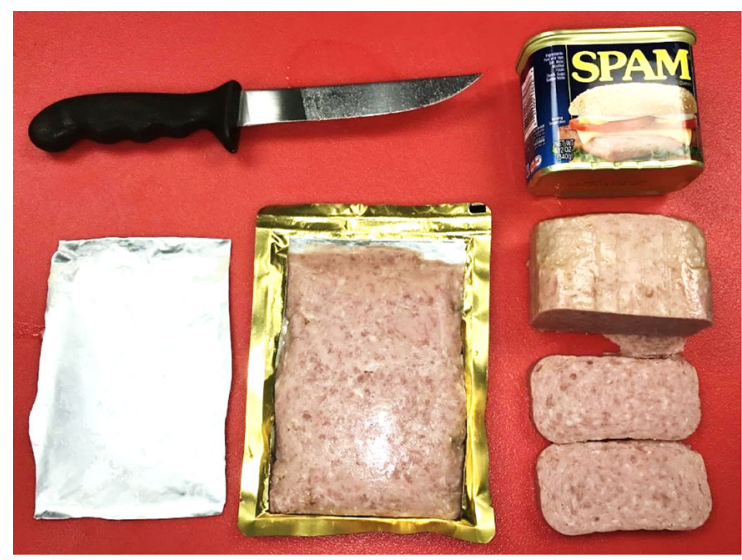

Fig. 1 A loaf of the artificial bait prior to cutting to size (left), and SPAM (right) for comparison

Field preference testing

Two separate field trials were conducted in Guam to evaluate BTS acceptance of modified bait formulations as well as address important questions regarding bait acceptance in naive BTS populations. Baits (without toxin) were placed in PVC tubes (Siers et al. 2019) suspended 1.5-2 $\mathrm{m}$ off the ground in trees or shrubs. To avoid affecting Endangered Species Actlisted species, trees were inspected for the presence of endangered species (specifically snails) and no tubes were placed on trees with evidence of snails; during trials, no snails were observed at any test location. Five transects (Fig. 4) were employed at each of two Andersen Air Force Base (AAFB) locations. Bait types were represented in each transect in an alternating pattern. Transects were separated by at least $50 \mathrm{~m}$

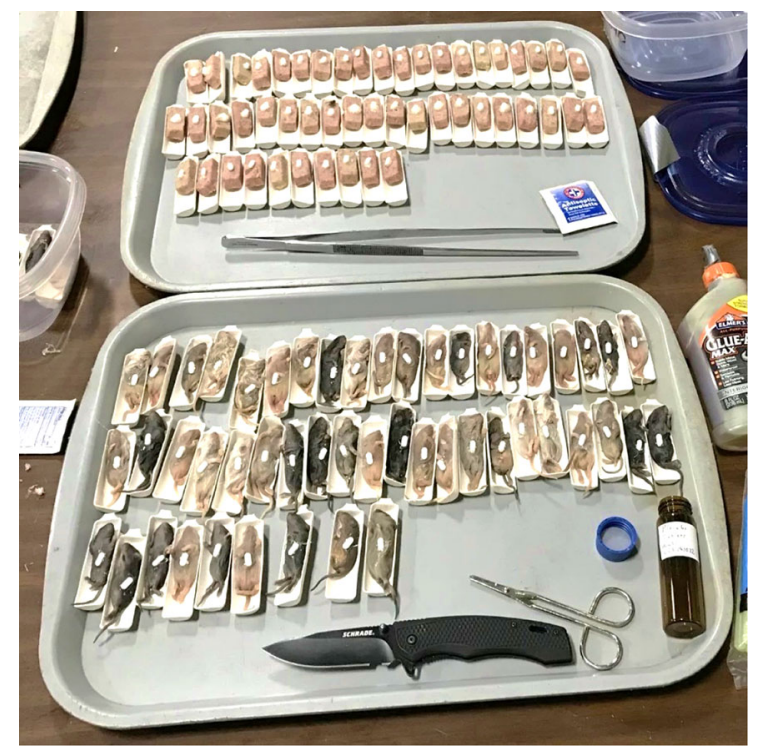

Fig. 2 Artificial bait trimmed to size (top) compared to dead neonatal mice (DNM; bottom). Both bait types are attached to half of an ADS bait cartridge capsule and have a placebo tablet attached to the bait

and walked daily by trained personnel to examine tubes for the presence or absence of baits. Missing baits were not replaced. Evidence of bait consumption by ants or other insects was noted.

\section{Field trial \#1}

The first field trial, conducted during the period of 4 August to 7 September 2019, was in two parts. Part 1A was replicated at both sites at AAFB (Fig. 5) to 
Table 2 Adhesive products screened in laboratory for artificial bait attachment. Select adhesives (indicated by ' $\mathrm{X}$ ') were carried forward into field durability and BTS preference trials

\begin{tabular}{|c|c|c|c|}
\hline Adhesive & Adhesive base & Field durability & BTS preference \\
\hline Gorilla super Glue Gel & Cyanoacrylate & $\times$ & $\times$ \\
\hline Elmer's Glue-all max & Polyurethane & $\times$ & $\times$ \\
\hline Fixodent Ultra & Unknown & $\times$ & \\
\hline Ground hide Glue & Gelatin & $\times$ & \\
\hline Elmer's Carpenter's Wood Glue Max & Polyvinyl acetate & $\times$ & \\
\hline Elmer's Rubber cement & Natural or synthetic rubber & & \\
\hline Yamato Nori rice sticking paste & Starch & & \\
\hline Mehron makeup spirit gum & Shellac & & \\
\hline $3 \mathrm{M}$ nitrile high performance rubber $\&$ gasket adhesive & Nitrile rubber & & \\
\hline Barge all purpose cement & Unknown & & \\
\hline Seal-all & Unknown & & \\
\hline Loctite clear silicone & Silicone rubber & & \\
\hline Korean glue beads & Polyamide & & \\
\hline Loctite epoxy marine & Epoxy resin & & \\
\hline Hot glue & Ethylene-vinyl acetate & & \\
\hline False eyelash glue & Unknown & & \\
\hline New-skin liquid bandage & Nitrocellulose & & \\
\hline
\end{tabular}

determine if either of two commercial adhesives (Gorilla Super Glue Gel and Elmer's Glue-All Max) influenced bait preference. Two different bait formulations employing the "original" mouse butter formulation (Table 1) and differing only in the presence or absence of pork fat (Table 3) were tested. The test adhesives (ca. $1.5 \mathrm{~cm}$ "dab") were applied directly to the baits; ADS capsules were not used in this test. Bait disappearance data were subjected to Kaplan-Meier failure analyses (Wilcoxon $\chi^{2}$ test of equality) and ranked (disappearance day ranked within transect) for Krusksal Wallis tests with rank the response variable and transect (10 transects of 24 tubes distributed across two sites), pork fat (presence or absence), adhesive (Gorilla Super Glue Gel, Elmer's Glue-All Max, or none), and pork fat*adhesive as fixed effects.

Part 1B was conducted during the period of 24 September to 19 October 2019 only at the Tarague site (Fig. 5) with bait formulations that differed in pork fat content and mouse butter formula (Table 4). Bait disappearance data were subjected to Kaplan-Meier failure analyses (Wilcoxon $\chi^{2}$ test of equality) and Krusksal Wallis test of ranked failure with transect and treatment (six bait types; Table 4) as fixed effects.
Field trial \#2

The second field trial was conducted at both AAFB locations (Fig. 5) during the period of 26 October to 17 November 2019. Two bait formulations with no added pork fat, BE-36 and BE-40 (Table 4) were tested along with DNM. The purposes for conducting this field trial were two-fold: First, we sought to have direct comparison of bait preference of the least expensive formulations with the "gold standard" bait, DNM. Second, nearly every prior field testing of artificial baits had been conducted at the Tarague site (Fig. 5). Out of an abundance of caution, we sought to demonstrate that bait preferences observed in prior studies at Tarague did not represent a populationspecific preferred bait formulation. The trial lasted 14 days. Bait disappearance data were subjected to Kaplan-Meier failure analyses (Wilcoxon $\chi^{2}$ test of equality) and Kruskal Wallis test of ranked failure with site, treatment (BE-36, BE-40, DNM), and site*treatment as fixed effects. Bait removal data (total, non-insect related removal at the end of 14 days) were also subjected to $\chi^{2}$ analyses. $\chi^{2}$ analyses were also used to determine if insect activity differed by site or bait type. 


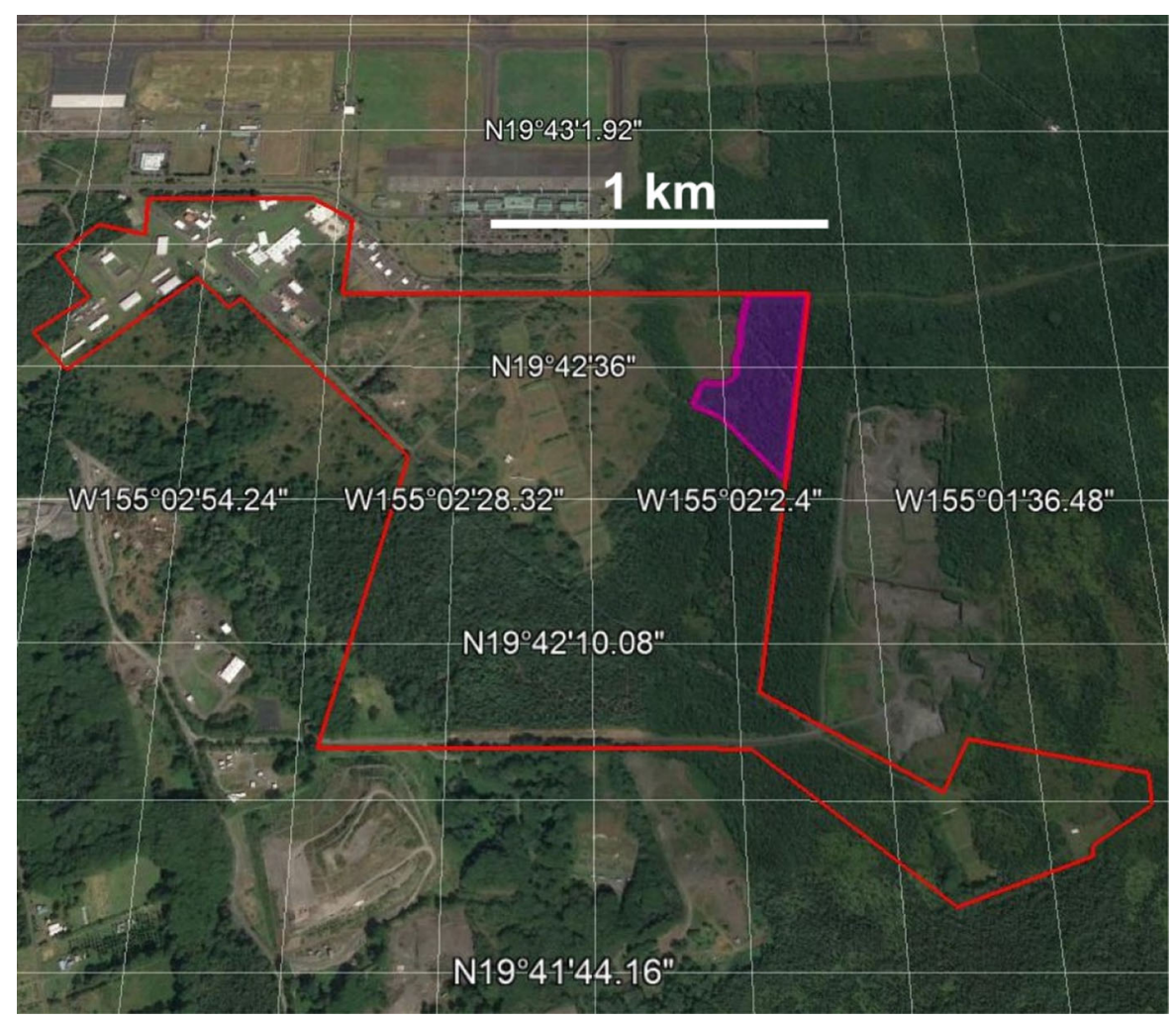

Fig. 3 Map of the Keaukaha Military Reservation in Hilo, HI (red outline). Bait adhesive testing was conducted in section designated "Area C" (purple shading)

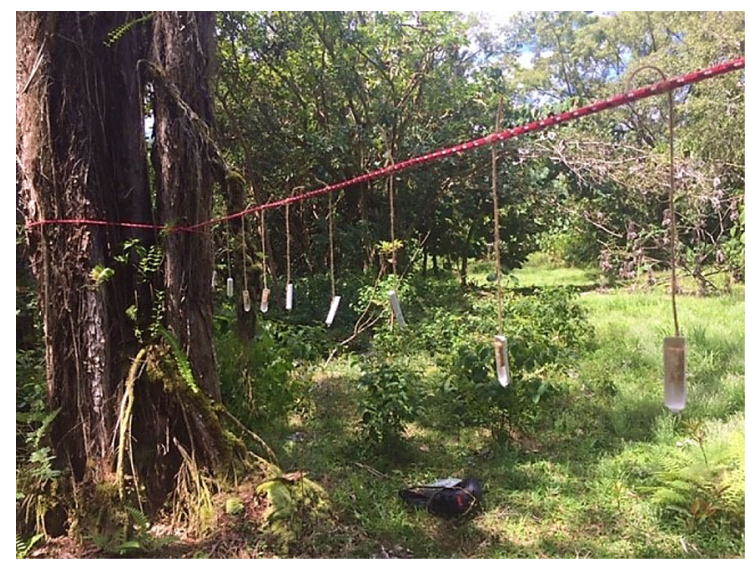

Fig. 4 Adhesive field testing, partial sun exposure transect

\section{Results and discussion}

Laboratory and field testing of adhesives

Most of the adhesives tested (12 of 17) made a very weak bond between the ADS capsule material and the artificial bait when tested in the laboratory and were clearly unsuitable. The failure of the adhesives was probably related to oily residue on the bait surface. Five adhesives passed a qualitative test by forming a bond sufficiently strong to hold a bait cube adhered to a vertical sheet of ADS capsule material, and only these adhesives were used in field durability trials (Table 2).

The ability of the five adhesives to keep the bait attached to the capsule for 14 days in the field differed among the adhesives tested $(P<0.0001$; Table 5), but not among the three test sites $(P=0.796)$. Further evaluation indicated that the number of attached baits remaining on day 14 did not differ statistically among Gorilla Super Glue Gel, Elmer's Glue-All Max, and Elmer's Carpenter's Wood Glue Max $(P=0.245)$. Based on total baits remaining attached to the capsule after 14 days (Table 5), the two best performing adhesives, Gorilla Super Glue Gel and Elmer's GlueAll Max, were chosen for further evaluation. 


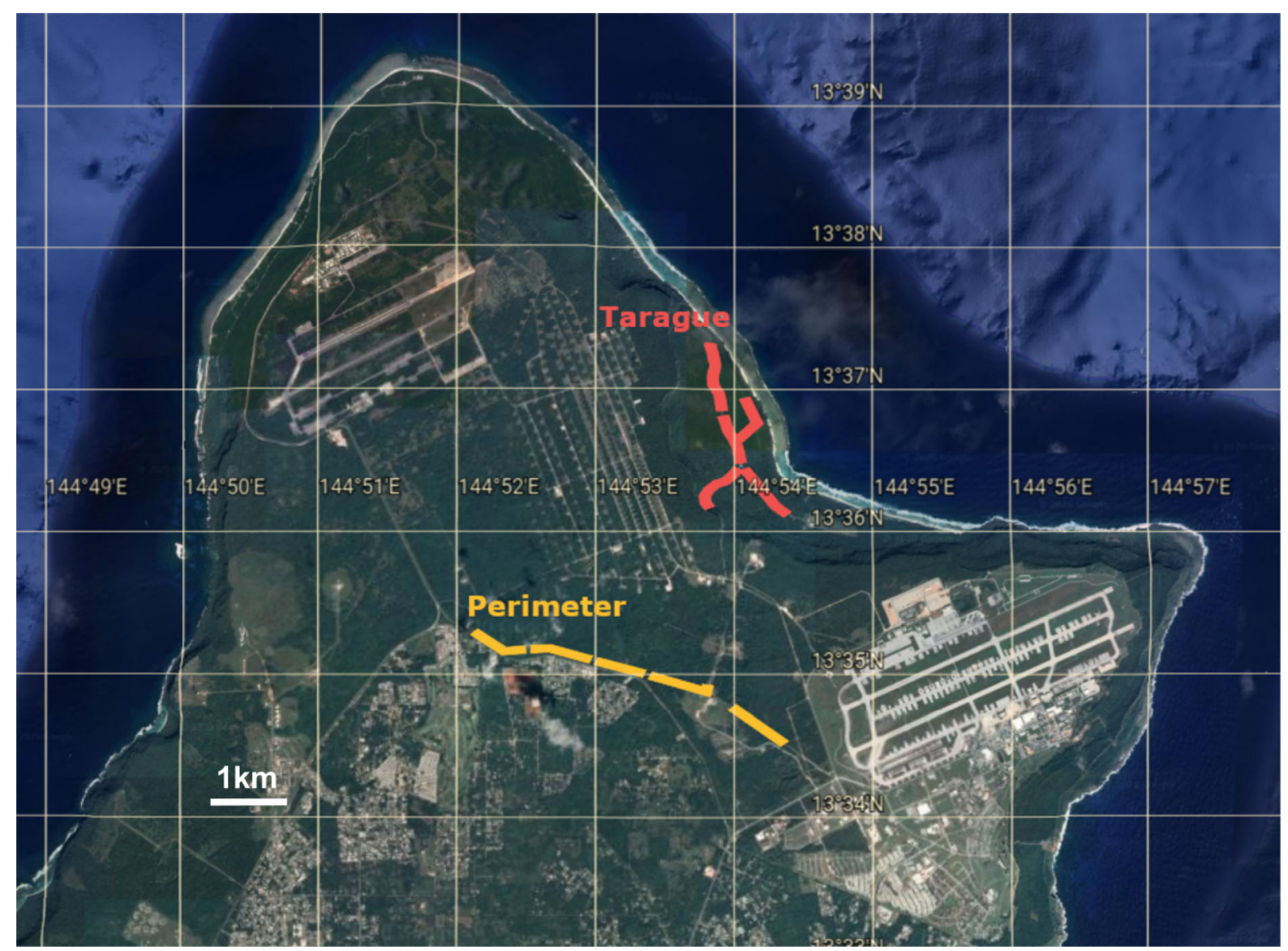

Fig. 5 Map of Andersen Air Force Base and the two sites used for bait testing

Table 3 Baits used in trial 1A to test the impact of two adhesives on BTS bait preference

Table 4 Six baits used in Trial $1 \mathrm{~B}$ to determine if cheaper sources of lipids could be used in the bait formulation. No adhesives used

\begin{tabular}{llll}
\hline Bait ID & Mouse butter formula & Pork fat $(\mathrm{g})$ & Adhesive \\
\hline BE-34 & Original & 209 & None \\
BE-34-GG & Original & 209 & Gorilla Super Glue Gel \\
BE-34-EG & Original & 209 & Elmer's Glue-All Max \\
BE-36 & Original & 0 & None \\
BE-36-GG & Original & 0 & Gorilla Super Glue Gel \\
BE-36-EG & Original & 0 & Elmer's Glue-All Max \\
\hline
\end{tabular}

\begin{tabular}{lrll}
\hline Bait ID & Mouse butter formula & Pork fat $(\mathrm{g})$ & Per unit bait materials cost \\
\hline BE-34 & Original & 209 & $\$ 0.27$ \\
BE-37 & EPO substitution & 209 & $\$ 0.11$ \\
BE-38 & Natural fats substitution & 209 & $\$ 0.03$ \\
BE-36 & Original & 0 & $\$ 0.23$ \\
BE-39 & EPO substitution & 0 & $\$ 0.10$ \\
BE-40 & Natural fats substitution & 0 & $\$ 0.03$ \\
\hline
\end{tabular}


Effect of adhesives on BTS preference (Trial 1A)

Disappearance of baits did not differ among the six baits (Wilcoxon $P=0.3993$; Table 6). Rank data did not differ among transects $(P=0.995)$, presence or absence of added pork fat $(P=0.335)$, adhesive type $(P=0.490)$, or the interaction of pork fat and adhesive $(P=0.354)$. These results indicated that the added pork fat does not suppress the performance of the bait, but also that it is an unnecessary ingredient. Elimination of the pork fat reduces the ingredient cost by a small amount, but also greatly reduces the amount of exuded fat observed when opening retort packages. The final choice of adhesive will have to consider integration into the manufacturing process, but these results indicate that neither Elmer's Glue-All Max nor Gorilla Super Glue Gel reduce bait acceptance by freeranging snakes.

Effect of mouse butter reformulation on BTS preference (Trial 1B)

BTS preference for six bait variants was studied; these baits differed in presence or absence of added pork fat and source of materials for preparing the mouse butter (Table 4). The mouse butter variants named EPO substitution and Natural fats substitution were formulated so that the ratios of fatty acids (i.e. arachidonic, lauric, myristic, palmitic, stearic, and linoleic) matched those of Original mouse butter, but with greatly reduced ingredient costs. Fat present in ground pork (and added pork fat) contribute significant amounts of oleic acid. Disappearance rates did not differ among the six baits tested (Wilcoxon $P=0.9497$; Table 7) and ranks did not differ among baits $(P=0.856)$. Thus, any of the three mouse butter formulas can be used for producing baits and there is
Table 6 Percentage of baits removed from bait tubes (not attributed to insects) in Trial $1 \mathrm{~A}$

\begin{tabular}{llll}
\hline Adhesive & BE-34 (\%) & BE-36 (\%) & Average (\%) \\
\hline None & 58.1 & 28.6 & 43.4 \\
Elmer's Wood Glue & 38.9 & 44.4 & 41.6 \\
Gorilla Glue & 43.6 & 51.4 & 47.5 \\
Mean & 46.9 & 41.5 & 43.9 \\
\hline
\end{tabular}

no interactive effect of mouse butter formula and presence or absence of added pork fat.

\section{Comparison of best baits and location testing (Trial} 2)

Three bait types were selected for "final" testing: DNM, artificial baits prepared with the original mouse butter mixture, and artificial baits prepared with natural fats. No pork fat was added to either of the two artificial baits. These three bait types represent the "best" baits at various stages of bait development over the past twenty years. DNM have long been considered the "gold standard" for BTS baiting activities (Savarie et al. 2001). The original mouse butter recipe was formulated in 2015 as a promising component of artificial baits after several years of development (Kimball et al. 2016). This study has demonstrated that the mouse butter prepared using natural sources of fats performs equally as well as the original formula and is substantially less expensive (Table 4).

Bait disappearance differed among the three treatments (Wilcoxon $P<0.0001$ ). As was anticipated, DNM were preferred in comparison to both of the artificial baits as evidenced by ranked data $(P<0.0001)$. Preference did not differ between the two artificial baits. However, disappearance of the

Table 5 Percentage of baits remaining attached to the capsule after 14 days

\begin{tabular}{llllll}
\hline Transect & $\begin{array}{l}\text { Elmer's glue-all } \\
\max (\%)\end{array}$ & $\begin{array}{l}\text { Elmer's Carpenter's wood glue } \\
\max (\%)\end{array}$ & $\begin{array}{l}\text { Fixodent ultra } \\
(\%)\end{array}$ & $\begin{array}{l}\text { Gorilla super glue } \\
\text { gel }(\%)\end{array}$ & $\begin{array}{l}\text { Behlen ground hide } \\
\text { glue }(\%)\end{array}$ \\
\hline A & 100.0 & 86.7 & 0.0 & 100.0 & 0.0 \\
B & 93.3 & 66.7 & 6.7 & 93.3 & 6.7 \\
C & 66.7 & 40.0 & 0.0 & 93.3 & 6.7 \\
Overall & 86.7 & 64.4 & 2.2 & 95.5 & 4.4 \\
\hline
\end{tabular}


Table 7 Percentage of baits removed from bait tubes (not attributed to insects) in Trial 1B

\begin{tabular}{ll}
\hline Bait ID & Removed (\%) \\
\hline BE-34 & 59.5 \\
BE-36 & 73.0 \\
BE-37 & 67.6 \\
BE-38 & 67.6 \\
BE-39 & 68.6 \\
BE-40 & 75.0 \\
Mean & 68.5 \\
\hline
\end{tabular}

artificial baits was extremely high (80\% and $79.7 \%$ for BE-36 and BE-40, respectively across both sites). Although these were lower than the rate for DNM $(98.7 \%)$, this represents a very significant improvement over any previous artificial bait material tested. In fact, many test baits are unattractive to BTS and result in less than 5\% acceptance (Savarie and Clark 2006). Relative preference among the bait types (as denoted by rank values) did not differ between sites $(P=0.748)$ or site*treatment $(P=0.90)$, indicating that DNM was preferred at both sites.

Although ranked data did not differ between sites, disappearance differed between sites $(P<0.0001)$, particularly for the test baits. Thus, while relative preference among treatments did not differ between sites, overall bait removal was not the same at the two sites. Removal of test baits at the perimeter site was sufficient, but much lower than the Tarague site (Table 8). The results at the Tarague site represent the first time that an artificial bait achieved 95\% acceptance in the field. Site-to-site variation in preference for the artificial baits was expected. The purpose of this trial was to assess such differences at two locations likely to represent unique BTS populations with limited overlap. The difference in artificial bait acceptance observed here may have been influenced by differences in snake density and/or prey availability/type at the two locations. However, it should be

Table 8 Percentage of baits removed from bait tubes (not attributed to insects) in Trial 2

\begin{tabular}{lllc}
\hline Site $^{\mathrm{a}}$ & BE-36 (\%) & BE-40 (\%) & DNM (\%) \\
\hline Perimeter & 54.5 & 54.2 & 97.1 \\
Tarague & 94.7 & 95.0 & 100.0 \\
\hline
\end{tabular}

${ }^{a}$ See map of sites in Fig. 5 noted that prior testing (approximately eight years) of pork-based baits and mouse butter formulas was conducted at the Tarague site in an iterative fashion (where results at Tarague informed decisions regarding bait modifications and further testing at Tarague). Thus, it remains possible that the bait formulation was optimized for BTS foraging characteristics in the Tarague Basin or that snakes resident to this area have become conditioned to the artificial bait. Foraging behavior and feeding preferences are strongly influenced by genetics, social learning, and prior experience with a food (Provenza 1995). In one snake species (Thamnophis sirtalis), it has been shown that prior experience with a food is a greater driver of feeding preferences in neonates versus adults (Krause and Burghardt 2001). However, lack of evidence in adults for the importance of prior experience may be a product of prey availability. Importantly, testing at only two locations is not sufficient to predict islandwide bait acceptance; however, removal of $>50 \%$ of test baits at a novel location is a very encouraging result.

$\chi^{2}$ analyses of insect observation data (Table 9) indicated greater ant and fly larva activity on the artificial baits as compared to DNM at the perimeter site $(P<0.0001)$; but not at the Tarague site $(P=0.109)$. However, it is important to note that familiarity of the sites did influence deployment of bait tubes; certain locations of the Tarague site were avoided due to known insect activity in past trials. Furthermore, artificial baits were viable for the entire 14 days of the trial, whereas 72 of the 80 DNM were consumed by day five and remaining DNM were rapidly decomposing. Thus, there was greater opportunity for insects to find and consume artificial baits. Previous photographic monitoring of DNM in bait tubes indicates that BTS will continue to consume bait swarmed with ants and fly larvae (Siers et al. 2019). An additional study to quantify differences in insect

Table 9 Percentage of baits with evidence of insect activity (ants or fly larvae) by site and bait type

\begin{tabular}{lccc}
\hline Site $^{\mathrm{a}}$ & BE-36 (\%) & BE-40 (\%) & DNM (\%) \\
\hline Perimeter & 45.0 & 40.0 & 12.5 \\
Tarague & 5.0 & 0.0 & 0.0 \\
\hline
\end{tabular}

${ }^{\mathrm{a}}$ See map of sites in Fig. 5 
interference with DNM and artificial baits has been funded and is currently in development.

Conclusion and future directions

This study successfully identified two adhesives that securely attach artificial baits to the ADS capsule without reducing bait effectiveness. Reformulations of the artificial bait achieved up to $89 \%$ reduction in ingredient cost and demonstrated excellent BTS acceptance in the field. Successful deployment of these baits will require additional development focused on four areas: (1) incorporation of the toxin (acetaminophen) into the bait matrix, (2) reduction of labor costs for bait mass production, (3) integration of the bait into the ADS cartridge production process, and (4) consideration of methods to reduce non-target bait consumption. Additional future work could include development of lipid mixtures mimicking birds or other BTS prey.

Acknowledgements These studies were made possible through funding provided by the U.S. Department of the Navy (MIPR\# M2002118MPDP075) and generous access to Andersen AFB. This research was supported in part by the intramural research program of the U.S. Department of Agriculture, Animal and Plant Health Inspection Service and Agricultural Research Service. The assistance of USDA APHIS Wildlife Services staff located on the island of Guam was greatly appreciated. Editor: Please include this statement. "Mention of trade names or commercial products in this publication is solely for the purpose of providing specific information and does not imply recommendation or endorsement by the U.S. Department of Agriculture. USDA is an equal opportunity provider and employer"

Funding Information that explains whether and by whom the research was supported: Funding provided by the U.S. Department of the Navy (MIPR\# M2002118MPDP075).

Data availability The datasets generated during and/or analyzed during the current study are available from the corresponding author on reasonable request.

\section{Declarations}

Conflict of interest The authors declare that they have no conflict of interest.

Consent for publication All authors have consented to publication of this manuscript.

Ethics approval Include appropriate approvals or waivers: NWRC protocol QA-3011 ("Artificial Toxic Bait Attachment and Field Stability for Landscape-scale Brown Treesnake
Suppression”) was approved by the Institutional Animal Care and Use Committee on 10/10/19.

\section{References}

Clark L, Clark C, Siers S (2017) Brown tree snakes: methods and approaches for control. In: Pitt WC, Beasley J, Witmer GW (eds) Ecology and management of terrestrial vertebrate invasive species in the United States. CRC Press, London

Engeman RM, Shiels AB, Clark CS (2018) Objectives and integrated approaches for the control of brown tree snakes: an updated overview. J Environ Manag 219:115-124. https://doi.org/10.1016/j.jenvman.2018.04.092

Freedman MG, Miller RH, Rogers HS (2018) Landscape-level bird loss increases the prevalence of honeydew-producing insects and non-native ants. Oecologia 188:1263-1272. https://doi.org/10.1007/s00442-018-4273-5

Fritts TH, Rodda GH (1998) The role of introduced species in the degradation of island ecosystems: a case history of Guam. Annu Rev Ecol Syst 29:113-140. https://doi.org/10. 1146/annurev.ecolsys.29.1.113

Johnston JJ, Savarie PJ, Primus TM et al (2002) Risk assessment of an acetaminophen baiting program for chemical control of brown tree snakes on Guam: evaluation of baits, snake residues, and potential primary and secondary hazards. Environ Sci Technol 36:3827-3833. https://doi.org/10. 1021/es015873n

Kimball BA, Stelting SA, McAuliffe TW et al (2016) Development of artificial bait for brown treesnake suppression. Biol Invasions 18:359-369. https://doi.org/10.1007/ s10530-015-1031-z

Krause MA, Burghardt GM (2001) Neonatal plasticity and adult foraging behavior in garter snakes (Thamnophis sirtalis) from two nearby, but ecologically dissimilar, habitats. Herpetol Monogr. https://doi.org/10.2307/1467039

Moore A, Jackson T, Quitugua R et al (2015) Coconut Rhinoceros Beetles (Coleoptera: Scarabaeidae) Develop in Arboreal Breeding Sites in Guam. Florida Entomologist 98:1012-1014. https://doi.org/10.1653/024.098.0341

Pollock HS, Fricke EC, Rehm EM et al (2020) Såli (Micronesian starling-Aplonis opaca) as a key seed dispersal agent across a tropical archipelago. J Trop Ecol 36:56-64. https://doi. org/10.1017/S0266467419000361

Provenza FD (1995) Tracking variable environments: There is more than one kind of memory. J Chem Ecol 21:911-923. https://doi.org/10.1007/BF02033798

Rodda GH, Savidge JA (2007) Biology and Impacts of Pacific Island Invasive Species. 2. Boiga irregularis, the Brown Tree Snake (Reptilia: Colubridae)1. Pasc 61:307-324

Savarie PJ, Clark L (2006) Evaluation of bait matrices and chemical lure attractants for brown tree snakes. Proc Vertebr Pest Conf. https://doi.org/10.5070/V422110077

Savarie PJ, Shivik JA, White GC et al (2001) Use of acetaminophen for large-scale control of brown treesnakes. J Wildl Manag 65:356-365. https://doi.org/10.2307/ 3802916 
Siers SR, Shiels AB, Barnhart PD (2020) Invasive Snake activity before and after automated aerial baiting. J Wildl Manag 84:256-267. https://doi.org/10.1002/jwmg.21794

Siers SR, Shiels AB, Payne CG et al (2019) Photographic validation of target versus nontarget take of brown treesnake baits. Wildl Soc Bull 43:752-759. https://doi.org/10.1002/ wsb. 1023

Vice DS, Engeman RM, Vice DL (2005) A comparison of three trap designs for capturing brown treesnakes on Guam. Wildl Res 32:355-359. https://doi.org/10.1071/WR04046
Vice DS, Pitzler ME (2002) Brown treesnake control: economy of scales. In: Human conflicts with wildlife: economic considerations. Proceedings of the Third NWRC Special Symposium. National Wildlife Research Center, Fort Collins, Colorado, USA

Publisher's Note Springer Nature remains neutral with regard to jurisdictional claims in published maps and institutional affiliations. 